\title{
O PÁTIO DOS BICHOS: \\ UM ESPAÇO DE LAZER PARA A CORTE PORTUGUESA DO SÉCULO XVIII
}

\author{
Isabel M. R. Mendes Drumond Braga \\ (Universidade de Lisboa, Faculdade de Letras e CIDEHUS-UE)
}

\section{RESUMO}

Este texto pretende problematizar a presença e o significado de animais exóticos na corte portuguesa do século XVIII. Não obstante o reino receber animais de outros continentes desde o século XV, só em setecentos criou, no palácio de Belém, uma ménagerie, denominada Pátio dos Bichos, um espaço específico de lazer e ostentação para a casa real e para a corte. O funcionamento deste jardim zoológico privado conhece-se através de documentação relativa especialmente à entrada de animais e gastos com os mesmos, mas também pelos escritos de estrangeiros que visitaram os jardins do palácio e a quinta de Belém.

PALAVRAS-CHAVE: Animais, Corte portuguesa, Jardim zoológico, Lazer, Pátio dos Bichos.

THE PATIO DOS BICHOS:

\section{A LEISURE AREA FOR THE PORTUGUESE COURT OF THE XVIII CENTURY}

\begin{abstract}
This text aims to problematize the presence and the meaning of exotic animals in the Portuguese court of the XVIII century. Although the kingdom received animals from other continents since the fifteenth century, it was only in the seventies that a ménagerie, called Pátio dos Bichos, was created in the palace of Belém, a specific space of leisure and ostentation for the royal house and the court. The management of this private zoo is known through documentation relating especially to the entrance of animals and expenses, but also by the writings of foreigners who visited the gardens of the palace and the farm of Belém.
\end{abstract}

KEY WORDS: Animals, Portuguese court, Zoological garden, Leisure, Pátio dos Bichos. 
A historiografia da atualidade tem dedicado bastante atenção à Corte, uma instituição mas também um meio social e um espaço físico. Neste texto, pretende problematizar-se o papel do Pátio dos Bichos, isto é, do espaço construído especificamente para albergar a primeira ménagerie portuguesa, enquanto espaço de lazer, mas também de ostentação, uma vez que o prestígio do possuidor, isto é, da Casa Real, era visível através da capacidade de obter, oferecer e receber animais. Tanto mais que, se esquecermos a Antiguidade Clássica, em especial o período em que o Império Romano se expandiu para espaços extraeuropeus, permitindo a tomada de conhecimento da fauna de outras paragens, foi, a partir do século XV, que o envolvimento de Portugal no processo expansionista conduziu o Reino à tomada de contacto com outras realidades. Viam-se, comentavam-se e descreviam-se novidades díspares que, para se tornarem inteligíveis, eram objeto de comparação com o que se conhecia. Porém, era necessário transportar para o velho mundo as novidades de outros mundos acabados de descobrir e, entre as muitas realidades diferentes, contavam-se novas espécies animais que deslumbraram os europeus. Colecionar e expor animais, criando jardins zoológicos, primeiro para deleite privado e mais tarde para todos, acabaram por ser evoluções expectáveis num percurso começado cedo.

1. Nas primeiras décadas do século XVI, Garcia de Resende (1470-1536), na sua obra Miscelânea, lembrou as «novas novidades, / grandes acontecimentos / e desvairadas mudanças» ${ }^{1}$, a que tinha assistido ao longo da sua vida. Neste poema, não se referiu apenas às alterações provocadas pelos Descobrimentos portugueses, mas refletiu sobre um vasto conjunto de mudanças políticas, sociais, económicas e culturais. No caso concreto da fauna de outras paragens, designadamente do continente africano, escreveu:

Tem elefantes pasmosos, / cobras de grande grandura, / lagartos mui espantosos, / gatos de algália cheirosos, / árvores de grande altura, / arroz, inhames, palmeiras, / gatos de muitas maneiras, / e papagaios de sortes, / cavalos-marinhos fortes, / que andam fora das ribeiras ${ }^{2}$.

Sem perdermos de vista que alguns animais de outras paragens não eram totalmente desconhecidos na Europa Medieval, foi a partir do reinado de D. João I, com a conquista de Ceuta, levada a efeito em 1415, que as realidades do continente africano, em especial as do litoral, se começaram a conhecer de uma maneira direta em Portugal. Mas foi com a chegada à India, em 1498, e com o descobrimento oficial do Brasil, em 1500, que as «novas novidades» foram jorrando. E, no que se refere à fauna das outras paragens, iniciou-se, por parte dos Portugueses, a observação dos animais nos seus meios naturais, a recolha e transporte dos mesmos, a oferta de parte

\footnotetext{
${ }^{1}$ Garcia de Resende, Crónica de Dom João II e Miscelânea (Lisboa: Imprensa Nacional Casa da Moeda, 1973), 335.

2 Ibidem, 345.
} 
dos exemplares que chegavam vivos a membros das famílias reais europeias e ao papado, ao mesmo tempo que se adaptaram espaços para os albergar.

Em Portugal, tal como em outros reinos europeus, esporadicamente, encontraram-se exemplares da fauna de outras paragens ${ }^{3}$. Se os leões eram as vedetas dos jardins zoológicos medievais, para usar a expressão de Thierry Buquet ${ }^{4}$, outros animais também causavam furor. Por exemplo, por ocasião do casamento da infanta D. Leonor, filha de D. Duarte e irmã de D. Afonso V, com o imperador Frederico III, em 1451, durante os festejos realizados em Lisboa, contou-se a exibição de um elefante «de grande corpulência», que segundo o diário do embaixador Nicolau Lanckman de Valckenstein, capelão imperial, desfilou no dia 17 de outubro, antes de uma luta em que participou o monarca e seu irmão mais novo, o infante $\mathrm{D}$. Fernando ${ }^{5}$.

2. As novidades da fauna fascinaram adultos e crianças, mas nem todos os animais eram suscetíveis de ser transportados de forma fácil e eficaz. Viagens morosas, necessidade de acomodar muitos víveres em espaços exíguos, condições atmosféricas difíceis, inicial desconhecimento da alimentação adequada às diferentes espécies e dos comportamentos em cativeiro (o que levou a que, no caso das feras, durante o século XVIII, algumas fossem capturadas jovens para melhor se controlarem ${ }^{6}$ ), tornavam a mortalidade dos animais uma possibilidade constante. Entre os mais fáceis de acomodar e de tratar e os muito exuberantes, contam-se os pássaros de plumagens coloridas e de canto agradável ${ }^{7}$. Daí não ser de estranhar o fascínio que provocavam e o desejo de os colecionar. Assim se compreende que tenham sido muito procurados enquanto presentes para ofertar a vários membros das famílias reais e a diversas dignidades para manter em casa e para enriquecer os jardins zoológicos, independentemente do facto de serem igualmente objeto de estudo, em especial durante o século XVIII.

Entre as famílias reais foi comum o envio de pássaros para presentear crianças e adultos, ao longo de toda a Época Moderna e mesmo ainda no século XIX. Alguns exemplos foram significativos. A rainha D. Catarina, consorte de D. João III,

\footnotetext{
${ }^{3}$ Sobre os jardins zoológicos medievais, cf. Anna M. Adroer i Tasis, "Animals exòtics als palaus reials de Barcelona", Medievalia, 8, (1989), 9-22; Dolores Carmen Morales Muñiz, "La fauna exótica en la Península Ibérica: apuntes para el estudio del coleccionismo animal en el Medievo Hispánico", Espacio, Tiempo y Forma, 3. ${ }^{a}$ série, 13 (2000) 240, passim.

4 Thierry Buquet, "Les Animaux exotiques dans les ménageries médievales", em Fabuleuses histoires des bêtes et des hommes, direção de Jacques Toussant (Namur : Trema, 2013), 105.

${ }^{5}$ Leonor de Portugal, imperatriz da Alemanha: diário da viagem do embaixador Nicolan Lanckman de Valckenstein (Lisboa: Edições Cosmos, 1992) 41.

${ }^{6}$ Ricardo Ferreira Ribeiro, "A Triste e mal sucedida epopeia transatlântica da onça que "morreo de raiveza ferrando os dentes num pao': o tráfico de animais no Brasil colônia”, III Encontro da ANPPAS, (Brasília: [s.n.], 2006), 11-12.

${ }^{7}$ Sobre as dificuldades de transporte e a utilização dos pássaros sob as óticas lúdica e científica, cf. Jean-Bernard Lacroix, "L'approvisionnement des ménageries et des transports d'animaux sauvages par la Compagnie des Indes au XVIII" siècle", Revue française d'histoire d'autre-mer, 65, 239, (1978) 153-179.
} 
detentora de vários animais, em particular aves exóticas e autóctones, enviou um açor ao futuro Filipe II, então seu genro, em 1554; no ano anterior, foi a futura nora, D. Joana, que recebeu um pássaro exótico, que suscitou o interesse de Carlos, neto da rainha de Portugal, o qual lhe escreveu. Tentando de imediato atender ao desejo da criança, D. Catarina fez-lhe saber que

porque eu desejo comprazer-lhe em todas as coisas em que tem gosto e contentamento, mandei saber por toda esta cidade se havia algum pássaro daqueles e achou-se somente um, o qual estava em muda, pelo que lho não mandei logo pelo perigo que correra tirando-o da muda ${ }^{8}$.

Este neto receberá ainda um elefante e uma zebra, em 1549, e um outro elefante, em 1562. Pessoas dentro e fora da família real de Castela foram igualmente contempladas com pássaros e até com macacos e gatos de algália oferecidos por D. Catarina 9 .

Filipe II, em 1582, durante a sua estada em Portugal, recebeu um elefante proveniente da Índia que remeteu para Castela como presente para o filho e herdeiro. O paquiderme seria exibido em Madrid e em San Lorenzo del Escorial, onde ficaria também um rinoceronte que já vivera em Lisboa, desde 1577. Em 1603, as presas do elefante foram enviados ao imperador Rodolfo II, por instâncias do seu embaixador junto de Filipe III ${ }^{10}$. No século XVIII, a oferta de animais entre as famílias reais peninsulares continuou. No final da vida, quando a rainha D. Mariana Vitória, viúva de D. José I, visitou seu irmão Carlos III, rei de Espanha, teve oportunidade de, em 1778, remeter um veado para a sua filha mais nova, D. Maria Francisca Benedita. De Lisboa, recebeu igualmente animais que partilhou com a sua família de nascimento: vários pássaros, entre os quais três periquitos. Aparentemente, D. Mariana Vitória, possuidora de uma «casa das gaiolas» partilhava o gosto da mãe por pássaros ${ }^{11}$. No

\footnotetext{
${ }^{8}$ Isabel M. R. Mendes Drumond Braga, Um Espaço, duas Monarquias: Inter-Relações na Península Ibérica no Tempo de Carlos $V$ (Lisboa: Centro de Estudos Históricos da Universidade Nova de Lisboa, Hugin Editores, 2001) 92-93.

${ }^{9}$ Sobre outras ofertas, cf. Almudena Pérez de Tudela, Annemarie Jordan Gschwend, "Renaissance menageries: exotics animals and pets at the Habsbourg courts in Iberia and Central Europe", Early Modern zoology: the construction of animals in science, literature and visual arts 1 (Leiden: Brill, 2007), 427-456; Annemarie Jordan Gschwend, "A Procura portuguesa por animais exóticos", em Cortejo triunfal com girafas: animais exóticos ao serviço do poder, (Lisboa: Fundação Ricardo do Espírito Santo Silva, 2009), 36, 40-41; Idem, The story of Süleyman: celebrity elephants and other exotics in Renaissance Portugal ([s. 1.]: A Pachyderm Production, 2010) 8-11; Idem, A Rainha colecionadora: Catarina de Austria, (Lisboa: Círculo de Leitores, 2012), 122-126.

${ }^{10}$ Felipe II un monarca y su época: un principe del Renascimiento (Madrid: Sociedad Estatal para la Conmemoración de los Centenarios de Felipe II y Carlos V, 1998) 655-656; Carlos Gómez-Centurión Jiménez, Alhajas para los soberanos: los animales reales en el siglo XVIII: de las leoneras a las mascotas de cámara ([Valladolid]: Junta de Castilla y Leon, 2011),150. Sobre os animais oferecidos a Espanha, cf. também Arturo Morgado García, La imagen del mundo animal en la España moderna (Cádiz: UCA, 2015).

${ }^{11}$ Cf. María Ángeles Pérez Samper, Isabel de Farnesio (Barcelona: Plaza Janés, 2003), 360; GómezCenturión Jiménez, Alhajas, 218-219, 300, 307, 314, 356, 388, passim.
} 
entanto, seu irmão, Carlos III parece que apreciava «toda a bicharia», pois a rainha viúva pediu a Martinho de Melo e Castro, e comunicou tal pedido à filha, D. Maria I, em 1778, que mandasse periquitos e algum «veadinho»e «tudo o que se puder achar de mais especial» ${ }^{12}$.

Nem só os pássaros eram objeto de presente. Por exemplo, numa carta de Francisco Inácio de Sousa Coutinho, embaixador de Portugal em Espanha, a D. Luís da Cunha Manuel, secretário de Estado dos Negócios Estrangeiros, datada de 10 de março de 1775, fica a saber-se que, na audiência que tinha tido com Carlos III, este «disse-me que gostara muito da zebra e que teria muito gosto de ter um casal» ${ }^{13}$. O pedido do monarca foi atendido, em 1777. Em outubro desse ano, a rainha D. Maria I enviou o equídeo e uma carta na qual solicitava à corte espanhola desse 20 moedas de ouro, isto é, 96.000 réis, ao recoveiro que havia sido encarregado do transporte do animal $^{14}$.

3. Animais incluídos em presentes diplomáticos estão presentes desde a Idade Média europeia. Era uma prática antiga, documentada no Egipto faraónico, que continuou no Próximo Oriente, na Antiguidade greco-romana e no Islão ${ }^{15}$, consequentemente o facto de a Europa medieval e moderna a ter continuado em nada faz estranhar. Os animais exóticos ao serem oferecidos contribuíam para a construção da imagem do monarca através do fausto, da riqueza, da raridade e do luxo. Quem oferecia um animal fora do comum era alguém que podia exibir o seu poder e que sabia cultivar relações de clientelismo. Note-se que os bichos exóticos eram caros e raros, consequentemente difíceis de obter e de manter pois implicavam possuir alojamentos adequados, despender quantias significativas em alimentos e cuidados veterinários e possuir capacidade económica para os renovar constantemente. Logo, os animais, e designadamente as feras, eram acessíveis a poucos, em especial monarcas e nobres mais importantes, uma vez que os restantes ficavam reduzidos à posse de algum pássaro vivo ou de algum exemplar embalsamado guardado nos gabinetes de curiosidades e à contemplação dos bichos nos jardins zoológicos régios ${ }^{16}$.

\footnotetext{
12 Todas estas informações foram obtidas em Paulo Drumond Braga, A Rainha discreta: Mariana Vitória de Bourbon (Lisboa: Círculo de Leitores, 2014), 107, 112-113, 139, 230.

13 ANTT, Ministério dos Negócios Estrangeiros, caixa 627, fol. não numerado.

14 ANTT, Casa Real, cx. 3106.

15 Gustav Loisel, Histoire des ménageries de l'Antiquité à nos Jours 1 (Paris : Octave Doins et Fils e Henri Laurens) 1912 ; François Bertrandy, "Remarques sur le commerce des bêtes sauvages entre l'Afrique du Nord et l'Italie (II ${ }^{\mathrm{e}}$ siècle avant JC, IVe siècle après JC)", Mélanges de l'École Française de Rome. Antiquité, 99, 1 (1987), 211-241 ; Buquet, "Les Animaux", 112 ; Idem, "Les ménageries arabes et ottomanes", SSMOCI - Société Suisse Moyen Orient et Civilisation Islamique, 38, n. ${ }^{\circ}$ especial (Tière l'Animal) (2014)16-19 ; Joan Pieragnoli, La cour de France et ses animaux (XVI'-XVII siècles) (Paris : PUF, 2016), 115-121, 271-273.

${ }^{16}$ Cf. Éric Baratay, "Des naturalistes dans les cages : l'exemple de Claude Perrault (1613-1688)", em La bête captive au Moyen Âge et à l'Époque Moderne, direção de Corine Beck e Fabrice GuizardDuchamp, (Amiens : Encrage, 2012), 164.
} 
A oferta, por parte de D. Manuel I (1469-1521), de um elefante a Leão X terá sido o presente mais mediático de um monarca português durante toda a Época Moderna. Em 1513, o rei de Portugal enviou uma embaixada de obediência ao sumo pontífice, encabeçada por Tristão da Cunha, a qual desfilou na cidade de Roma, no ano seguinte. O cortejo integrava um elefante oferecido pelo rei de Portugal ao sumo pontífice por ocasião da coroação deste, o qual foi conduzido por um indiano, um nair ou mahout, proveniente de Goa, vestido de acordo com os usos locais. Esta comitiva exótica teve uma função propagandística utilizada para construir positivamente a imagem do rei e do reino. O paquiderme, a quem Leão $\mathrm{X}$ deu nome de Hanno, ficou alojado no jardim papal do palácio de Belvedere e, mais tarde, mudado para um edifício localizado na praça de São Pedro. Participou inclusivamente em procissões. Esta embaixada e o impacto que o animal causou, inclusivamente nas artes e nas letras, quer durante a viagem quer em Roma, foram impressionantes ${ }^{17}$. Além do elefante seguiram outros bichos incluídos no régio presente, designadamente antílopes, gazelas, macacos e papagaios. Leão X pôde, deste modo, aumentar os efetivos do seu jardim zoológico, que contava com aves, macacos, leões, leopardos e ursos, de entre outros, habitualmente reforçado com espécies provenientes das ménageries da sua família, estante em Florença ${ }^{18}$.

Para o Sacro Império Romano Germânico também seguiram elefantes. O primeiro em 1551 e o segundo em 1563. Efetivamente, em 1549, D. Catarina, rainha de Portugal, presenteou o seu neto Carlos, filho do príncipe Filipe e de sua filha Maria, com um elefante oriundo do Ceilão, atual Sri Lanka, a que chamaram Suleimão. Face aos problemas de acomodação e aos gastos com o animal, a corte de Castela optou por oferecê-lo a um primo segundo do primeiro dono, o futuro imperador Maximiliano II e sua mulher Maria, em 1551, quando o casal se retirou para Viena. O paquiderme faleceu dois anos depois, causando consternação. Mais tarde, em 1562, D. Catarina voltou a oferecer ao neto Carlos um elefante que, de novo, foi remetido à corte de Viena, após longa viagem marítima e terrestre. Desconhece-se o nome deste paquiderme, que permaneceu no Império até à sua morte, presumivelmente em 1577 ou após esse ano. Tal como outros elefantes encantou e inspirou escritores e artistas, sendo imortalizado por Arcimboldo, que o pintou, além de ter encantado a população local que teve oportunidade de o contemplar ${ }^{19}$.

O rinoceronte terá sido um dos animais que mais terá impressionado, dadas as características físicas, completamente diferentes das de outros animais existentes então na Europa. Chegou do Oriente, em 1515, através de Goa, e integrou um

\footnotetext{
17 Silvio A. Bedini, The pope's elephant (Manchester: Carcanet Press, 1997); Paulo Lopes, Um agente Português na Roma do Renascimento (Lisboa: Temas e Debates, Círculo de Leitores, 2013).

18 Bedini, The pope's, 83-84.

${ }^{19}$ Ibidem, 111-135; Tudela, Gschwend, "Renaissance", 431-432; Gschwend, The story; Mariagrazia Russo, "Un Elefante per bagaglio tra arte, storia e letteratura: il regalo di D. João III a Massimiliano d'Austria attraverso l'Europa del Cinquecento", em Viaggio con José Saramago, Bagagli e Oggetti da Viaggio, direcção de Cinzia Capitoni, (Viterbo: Sette Città, 2011), 23-36.
} 
presente do sultão de Cambaia, que pretendia manter boas relações com os Portugueses estabelecidos há pouco naquela zona. Após uma viagem de três meses, o paquiderme, de nome original Ganda, conheceu um novo nome dado pelos marinheiros, o de Ulisses, desembarcou em Lisboa para gaudio de nacionais e de estrangeiros particularmente curiosos acerca da pele e do chifre. $\mathrm{O}$ rinoceronte tentou combater com um elefante, testando-se, assim, a ancestral inimizade dos dois paquidermes. O primeiro saiu vencedor, sem luta, perante um elefante que se mostrou tímido e fugidio. Poucos meses depois, D. Manuel I decidiu oferecer Ganda ao Papa Leão X. A viagem rumo a Roma, ao contrário do que tinha acontecido à que realizara entre o Oriente e a Europa, foi acidentada, de tal modo que a embarcação naufragou perto de Génova. Francisco I, rei de França, não resistiu à curiosidade e foi contemplar o paquiderme em Marselha, onde a embarcação fez escala e Dürer celebrizou a figura através de uma gravura realizada em Nuremberga, a partir de um desenho provavelmente enviado pelo impressor Valentim Fernandes. Dürer juntou alguns elementos imaginários, como um segundo chifre e a pele tipo armadura metálica ${ }^{20}$. Enfatize-se que a troca de presentes diplomáticos tem sempre um valor simbólico, variando de acordo com as ocasiões e constituindo um momento privilegiado para mostrar as riquezas e o poderio de cada reino ${ }^{21}$.

4. D. Manuel I foi um colecionador entusiasta de bichos dos outros continentes. Damião de Góis, ao traçar o retrato do monarca, quer do ponto de vista físico quer do ponto de vista das características psicológicas, não deixou de referir que

foi o primeiro rei cristão da Europa a que vieram elefantes da Índia, dos quais teve cinco juntos, quatro machos e uma fêmea, que quando cavalgava pela cidade ou caminhava iam diante dele, a estes precedia (tão afastada que se não viam) a ganga ou rinoceronte, e atrás dos elefantes ia diante de el Rei um cavalo acobertado persa, nas ancas do qual um caçador persa levava uma

\footnotetext{
${ }^{20}$ Michel Pastoureaux, Les animaux célébres (Paris : Arléa, 2008), 183-191.

${ }^{21}$ Lucien Bély, Espions et ambassadeurs au temps de Louis XIV (Paris : Fayard, 1990), 378 ; Deborah Howard, "Cultural transfer between Venice and the Ottomans in the fifteenth and sixteenth centuries," em Cultural exchange in Early Modern Europe: forging european identities: 1400-1700, 4, (Cambridge: Cambridge University Press, 2007), 38-177; Maureen Cassidy-Geiger (director). Fragile diplomacy: Meissen porcelain for European courts ca. 1710-68 (Nova Iorque, Yale University Press, 2008; Jean-François Solnon, Le turban et la stambouline: l'empire Ottoman et l'Europe, XIV'-XX siècles: affrontement et fascination réciproques (Paris: Perrin, 2009), 119-125; Lucette Valensi, Ces étrangers familiers: musulmans en Europe (XVI-XVIII siècles) (Paris: Éditions Payot \& Rivages, 2012), 235-239; Almudena Pérez de Tudela, "Algunos regalos diplomáticos devocionales para Felipe II y su familia", in La Corte en Europa: política y religión (siglos XVI-XVIII), direção de José Martínez Millán, Manuel Rivero Rodriguez, Gijs Versteegen (Madrid: Polifemo, 2012), 1795-1849; I Doni di Shah Abbas il grande alla Serenissima: relazioni diplomatiche tra la Repubblica di Venezia a la Persi Safavide, dir. Elisa Gagliardi Mangiilli, (Veneza: Marsilio Editori, 2013); Gözde Önder, "Ceramics and carpets: icons of cultural exchange between Venice and the Ottoman Empire in the 16th Century", Diogenes, 2 (2014), 70-94.
} 
onça de caça que lhe mandara el rei de Ormuz, a qual onça e um elefante e rinoceronte mandou ao Papa Leão 22 .

Apesar de o cronista não fornecer informações mais pormenorizadas acerca dos animais, em especial, quem cuidava deles, de que se alimentavam ou em quanto importavam os gastos com o que lhes era destinado, sabe-se que o rinoceronte viveu no Paço da Ribeira e os elefantes nos Estaus. Note-se que, em 1500, já Diogo Velho, em poema dedicado à caça, referia: «Onças, leões, elefantes, / monstros e aves falantes, / porcelanas, diamantes, / é já tudo mui geral» ${ }^{23}$.

Os espaços com ligações mais fortes ao comércio internacional, durante a Idade Média, ou os reinos com espaços ultramarinos, ao longo da Época Moderna, foram mais facilmente abastecidos de animais para constituírem os seus jardins zoológicos. Assim, a Península Itálica pôde prover os seus serragli com facilidade, mas rapidamente a Península Ibérica irá suplantar esta forma de abastecimento devido aos impérios ultramarinos que constituiu. De qualquer modo, importa ter em atenção que inicialmente houve sempre dois grandes grupos de fauna: a autóctone, especialmente cinegética; e a importada em número mais escasso e muito mais valorizada, independentemente das imprecisões conceptuais serem enormes, havendo várias designações para o mesmo animal ${ }^{24}$.

Aparentemente, terá sido D. Dinis, o primeiro monarca português a manter animais selvagens em cativeiro, ainda no século XIII. No caso, tratou-se de um urso e de um lobo, dois exemplares da fauna cinegética autóctone que ficaram numa quinta em Frielas ${ }^{25}$. Na primeira metade do século XV, D. Afonso V possuiu um elefante $^{26}$ mas foi com D. Manuel I que os animais da fauna exótica passaram a fazer parte da coleção régia de forma mais recorrente. O monarca, como já se referiu, recebeu gazelas, antílopes e um rinoceronte de África, além de elefantes da Índia ${ }^{27}$. Após a Restauração, D. João IV obteve um leão, proveniente de África, que ficou nos Paços da Ribeira ${ }^{28}$. Mas todos estes dados são dispersos, demonstrando pequenas e descontínuas coleções zoológicas. A situação irá mudar sobretudo durante o século XVIII, quando se criou e dotou um espaço específico e apropriado para desfrutar da presença dos animais.

22 Damião de Góis, Crónica do felicíssimo rei D. Manuel (Coimbra: Imprensa da Universidade de Coimbra, 1955), IV parte, cap. 84, 224-225.

23 Cancioneiro Geral de Garcia de Resende 4 (Lisboa: Imprensa Nacional Casa da Moeda, 1993), 150.

${ }^{24}$ Sobre os problemas concetuais, cf. Morales Muñoz, "La fauna", 234-236; Gómez-Centurión Jiménez, Alhajas, 88-89.

${ }^{25}$ Inácio de Vilhena Barbosa, Apontamentos para a História das Colecções e dos Estudos de Zoologia em Portugal (Lisboa: Cristóvão Augusto Rodrigues, 1885), III-IV.

${ }^{26}$ Leonor de Portugal, 41.

${ }^{27}$ Gomes de Brito, "Os pachidermes do Estado d'el-rei D. Manuel”, Revista de educação e ensino e archivo de inéditos históricos, 9, (1894), 79-86; Abel Fontoura da Costa, Deambulations of the rbinoceros (Ganda) of Murafar, king of Cambaia, from 1514 to 1516 (Lisboa: Agência Geral das Colónias, 1937).

${ }^{28}$ Barbosa, Apontamentos, VII. 
Ora, importa introduzir algumas reflexões acerca da noção de coleção e das diferenças entre o juntar animais no século XVI e na centúria de setecentos. Foi exatamente a criação dos gabinetes de curiosidades que implicou a noção de coleção. O lexicólogo Rafael Bluteau (1668-1743) registou no seu Vocabulario Portuguez e Latino, publicado entre 1712 e $1728^{29}$, os termos coleção, curiosidade e gabinete. Porém, nunca os associou. Ou seja, coleção era sinónimo de ajuntamento ${ }^{30}$, gabinete de camarim ou contador ou ainda de aposento particular do príncipe ou do ministro em que estavam os papéis ${ }^{31}$, enquanto curiosidade foi definida de forma pouco lisonjeira, isto é, "desordenado desejo de ver ou de saber coisas novas ou que não são úteis nem necessárias" 32 , a par de outra aceção em que se definia como aplicação dos que investigam coisas ocultas. De fora ficaram questões como os significados dos gabinetes de curiosidades e das coleções, de forma mais aprofundada do que um mero juntar de peças. Por seu lado, a Encyclopédie, de Diderot e de d'Alembert, de 1752, na entrada "Cabinet", forneceu diversas aceções da palavra, incluindo referências a gabinetes de História Natural ${ }^{33}$.

Se bem que o termo coleção tenha aparecido em Inglaterra ainda no século XVII, tendo começado por ser aplicado a um conjunto de vegetais, o alargamento do significado rapidamente se deu. Sem entrarmos nas diferentes aceções dos termos coleção e colecionismo, que ocuparam muitos autores da atualidade, tentemos sistematizar algumas ideias chave relativas à matéria. Parece claro que qualquer peça é colecionada quando troca a sua utilidade pelo seu significado, o que apela às apropriações culturais como o aspeto mais significativo de uma coleção. Assim, nem toda a junção de objetos artísticos pode ser considerada automaticamente uma coleção de arte, pois a existência da mesma é mais do que o repertório de bens, implicando a relação que os proprietários têm com as peças ${ }^{34}$. Por outro lado, aspetos como o valor estético, o valor histórico, a raridade e o prestígio do anterior possuidor são variáveis a ter em conta no colecionismo, que ganha forma de atividade económica quando o objeto se desliga da sua funcionalidade imediata ${ }^{35}$.

\footnotetext{
${ }^{29}$ Sobre Bluteau, cf. Isabel M. R. Mendes Drumond Braga, "D. Rafael Bluteau na Corte Portuguesa (1668-1734," Cultura, Religião e Quotidiano. Portugal (século XVIII) (Lisboa: Hugin, 2005) 7-82.

${ }^{30}$ Rafael Bluteau, Vocabulario Portuguez e Latino, 2, (Coimbra, Real Colégio das Artes da Companhia de Jesus, 1712), 373.

${ }^{31}$ Rafael Bluteau, Vocabulario Portuguez. e Latino, 4, (Coimbra: Real Colégio das Artes da Companhia de Jesus, 1713) 3-4.

32 Ibidem 4, 642.

${ }_{33}$ Blondel, Daubenton, Diderot, d'Alembert, "Cabinet", Encyclopédie ou Dictionnaire Raisonné des Sciences, des Arts et des Métiers, direção de Denis Diderot e Jean le Rond d'Alembert, (Paris: Chez Briasson, David, l'Ainé, Le Breton e Durand), 1752, 488-493.

${ }^{34}$ Antonio Urquízar Herrera, Coleccionismo y Nobleza. Signos de Distinción Social en la Andalucía del Renascimiento (Madrid: Marcial Pons, 2007), 18-22.

${ }^{35}$ José Alberto G. Machado, Um Coleccionador Português do século das Luzes: D. Frei Manuel do Cenáculo Vilas-Boas, Arcebispo de Évora (Évora: Publicações Ciência e Vida, 1987), 11-12.
} 
Os gabinetes de curiosidades começaram a encantar a Europa no final da Idade Média. Wunderkammer - câmara de maravilhas - e Schatzammer - câmara de tesouros - dos principados alemães proliferaram no século XVI. Apresentavam conjuntos diversificados de objetos ao sabor da moda, das oportunidades de os obter e do gosto pelo raro e pelo diferente, tentando criar num microcosmos um espelho do macrocosmos, mas não foram as únicas vias de guardar curiosidades, maravilhas ou tesouros. Na Península Itálica, e em especial em Roma, foram sobretudo os objetos resultantes de viagens ao Oriente levadas a efeito por missionários e as peças provenientes de escavações arqueológicas das necrópoles etruscas e das catacumbas que constituíram as coleções dos gabinetes de curiosidades ${ }^{36}$. Por outro lado, na Península Ibérica, se as chamadas viagens filosóficas foram responsáveis pelo aumento significativo de espécimes suscetíveis de serem colecionados, já antes havia muitos objetos transportados por mercadores e por mareantes que podiam ser comprados e utilizados para puro deleite dos seus proprietários.

Pode dizer-se que os gabinetes de curiosidades continham dois grandes grupos de objetos: naturalia e artificialia. Começaram por resultar do interesse de particulares da Casa Real, da nobreza e do clero que os contemplavam para deleite pessoal e, em alguns casos, para estudo. Tendencialmente, estes espaços focaram-se, cada vez mais, no que não era fora do comum, isto é, no que decorria das leis da natureza. Porém, o exótico, designadamente o animal exótico, constituiu sempre um forte apelo. É, neste sentido, que o Pátio dos Bichos apareceu, constituindo um espaço específico para alojar animais, provenientes em especial dos espaços ultramarinos, e vocacionado para o lúdico e não para o estudo, ao contrário do que aconteceu com o Jardim Botânico, pois não se conhecem estudos de naturalistas a partir dos bichos régios.

A partir de 1726, D. João $\mathrm{V}$ juntou às residências régias, por aquisição no valor de 200.000 cruzados, as quintas e o palácio que o conde de Aveiras possuía em Belém. Será em parte deste espaço que se irá instalar a coleção zoológica da Corte, valendo-lhe a designação de Pátio dos Bichos. O jardim começou por albergar viveiros de aves, além de lagos, fontes e cascatas. Estes viveiros eram «divididos em muitos repartimentos tendo cada um destes no meio um lago de mármore com repuxo alto e nele uma taça para as aves beberem ${ }^{37}$, além de gradeamento e estátuas e vasos com personagens mitológicas.

Imediatamente após o terramoto de 1755 , D. José I mandou abater as feras do Pátio dos Bichos, designadamente felinos, ursos e «animais muito raros», segundo expressão de uma testemunha ${ }^{38}$, receando que se soltassem e causassem mais

\footnotetext{
${ }^{36}$ Beatrice Palma Venetucci, Dallo Scavo al Collezionismo. Un Viaggio nel Passato dal Medioevo all'Ottocent, (Roma: De Luca Editori, 2007) 113-117.

${ }^{37}$ Inácio de Vilhena Barbosa, "Palácio Real de Belém", Archivo Pittoresco, 5, 28, (1862), 217-218; Idem, Ibidem, 5, 29, 228-229.

38 O Terramoto de 1755: narrativa de uma testemunha ocular (Lisboa: Livraria Ferin, 1953), 17.
} 
problemas $^{39}$. Recordemos que os monarcas portugueses encomendavam às pessoas que desempenhavam cargos nos espaços ultramarinos o envio de animais africanos, brasileiros e orientais. Era essa a forma mais recorrente de então se obterem os bichos. Passados os momentos mais dramáticos, os envios foram retomados para refazer a coleção do Pátio dos Bichos.

Havia preocupações em cuidar dos animais para que chegassem vivos ao destino, embora nem sempre todos os envolvidos no processo tenham sido escrupulosos. Por ofício de 1774, o governador e capitão geral da capitania de Pernambuco, Manuel da Cunha Meneses, atribuiu a morte de vários pássaros «ao descuido dos capitães pela falta de tratamento, mas para que este seja mais frutuoso vão agora e irão os seguintes em viveiros com divisões mais espaçosas que desse melhor lugar à limpeza deles e suas acomodações de que lhe resulte mais proveitosa conservação» ${ }^{40}$. De qualquer modo, algumas pessoas eram cuidadosas. Conhece-se uma lista de mantimentos e uma outra do conteúdo da botica destinada aos animais que viajaram na corveta Nossa Senhora do Carmo e São Vicente Ferrer, proveniente de Angola, que fez escala no Brasil e se dirigiu a Portugal, em 1765. Os bichos foram alimentados com capim seco, canas doces, arroz de casca, milho e mel. Se algum teve necessidade de cuidados veterinários pôde contar com bolo arménio, basilicão, jeropiga, óleo de macela, óleo de louro, tintura, triaga magna e ervas emolientes e laxantes $^{41}$. Por outro lado, gaiolas e jaulas deveriam ser apropriadas para impedir que os animais se evadissem. Sabe-se que os viveiros de arame eram mais seguros do que os de cana, que permitiam a fuga de algumas aves, segundo ofício de 1783, da autoria do governador e capitão geral da capitania de Pernambuco, José César de Meneses ${ }^{42}$.

Com o passar do tempo, também se foram conhecendo melhor os hábitos alimentares dos animais, evitando que morressem durante as viagens marítimas. Aspeto interessante respeita ao facto de rapidamente se ter optado por tentar tornar mansas as espécies selvagens. Assim se compreende que alguns animais fossem capturados quando ainda eram muito jovens para, em seguida, serem criados em cativeiro e, posteriormente, remetidos a Lisboa ${ }^{43}$. Em ofício de 1778, José César de Meneses fez saber que enviava «duas porquinhas chamadas do mato, porém criadas em casa e muito mansinhas» ${ }^{44}$. Anos depois, era a vez de um ofício de outro governador e capitão geral da mesma capitania, Caetano Pinto de Miranda Montenegro, informar que iria remeter

\footnotetext{
${ }^{39}$ Caetano Beirão, “O Terramoto de Lisboa de 1755: novos documentos”, Panorama, III série, 1, (1956), p. não num.

40 Almeida, Papavero, Teixeira, “Animais”, 26.

41 Ibidem, 20-21.

42 Ibidem, 23-24.

${ }^{43}$ Ribeiro, "A Triste", 11.

44 Almeida, Papavero, Teixeira, "Animais”, 33.
} 
uma onça preta, a que chamam no Brasil onça tigre, a qual sendo apanhada muito pequena e criada em casa está tão mansa e doméstica que brinca não só com os que lhe dão de comer mas ainda com outra qualquer pessoa com quem facilmente se acostuma sem que tenha mostrado, desde que é minha, indício algum da sua fereza natural ${ }^{45}$.

Porventura, as menos conhecidas observações do Pátio dos Bichos devem-se a embaixadores marroquinos. Foram registadas por frei João de Sousa, o intérprete que, no âmbito do estabelecimento e da consolidação das relações diplomáticas entre Portugal e Marrocos, deixou relatos escritos de todas as missões. Em três delas encontram-se referências ao jardim zoológico da Corte. A descrição mais completa foi feita a propósito da visita de Omar Ben Daoudi, em 1774. Frei João de Sousa não se furtou a pormenores acerca dos animais observados ao longo de dois dias, ao mesmo tempo que não deixou de referir o espanto que causaram ao embaixador, designadamente o elefante e as zebras. Idênticas reações tiveram Hadj Abdelmajid Lazrak, em 1777-1778, e Hadj Mohammed Laanaïa, em 1780. O relato da visita à quinta do Palácio de Belém, em 1774, foi particularmente expressivo:

Ali o esperava [ao embaixador Omar Ben Daoudi] o Doutor João Rodrigues de Vilar com alguns criados de Sua Majestade, os quais depois de o cortejar o conduzirão pela rua principal atá o sítio onde estava o elefante, cuja vista lhe causou grande espanto por nunca os ter visto. Louvou a Deus e a sua omnipotência que o criou e pela sujeição que lhe pôs ao homem sendo hum animal tão grande. Fez varias perguntas sobre a sua criação e mantimento e para que o visse comer lhe deram os moços da quinta alguma hortaliça e vinho para beber. Dali foi ver o tanque dos peixes da China que o não admiraram menos por serem de cores fora do natural. Depois mostraramlhe os viveiros dos pássaros de que gostou de ver pela diversidade das suas cores qualidade. Tendo visto a parte superior da quinta passou às casas, jardim e varanda onde se recriou com a vista deliciosa do rio e praça de Belém e para nada lhe restar a ver o conduziram para o Pátio dos Bichos onde viu os que ali estavam: E como fosse tarde se recolheu para casa em companhia do condutor, o qual logo se despediu e foi para o Paço. Dia 28. $\mathrm{Na}$ manhã deste dia veio João António Pinto saber como passara e depois de lhe fazer os costumados cortejos o convidou para de tarde ir ver as zebras e cavalariça dos ursos de que ele tinha grande desejo de ver. Aceitou o embaixador o convite e lhe agradeceu os contínuos favores que lhe fazia e feita a visita se retirou o condutor para dispor as carruagens para a tarde. Tendo jantado chegou o coche em que costumava montar e tanto que veio o condutor montaram e as pessoas que o acompanhavam na mesma formalidade que costumavam e foram para o pátio onde estavam as zebras, indo juntamente sua guarda e criados a pé. Quando o embaixador as viu ficou de tal modo suspenso que voltando-se para o intérprete e com acenos e palavras lhe perguntou: que é isto, que animais são estes? Respondeu-lhe eram animais bravos e que tinham vindo e [tinham sido] achados em Angola

45 Ibidem, 42. 
e que sendo hum só casal tinham multiplicado neste Reino. Replicou o embaixador se a cor e pintas eram naturais ou artificiais o intérprete lhe disse que aquela cor era a que Deus lhes havia dado, ficou com aquela resposta ainda mais admirado e louvou muitas vezes ao criador pela sua omnipotência. Ali fez várias perguntas e averiguações sobre o mantimento e tratamento dos referidos animais e modo de os criarem e se eram domáveis, ao que tudo se lhe respondeu. Ele não se podia separar daquele sítio pela grande satisfação em que estava, porém como tinha de ver a cavalariça dos ursos com violência se retirou a pé acompanhado de toda a sua comitiva e se encaminharam a ver a cavalariça imediata. Daí passou à outra praça onde estavam os ursos e bons cavalos em que Sua Majestade monta ${ }^{46}$.

Quantos animais viveram no Pátio dos Bichos, em cada momento? De que se alimentou cada espécie? Quantas refeições eram servidas diariamente? Em quanto importaram? Quais os cuidados veterinários de que beneficiavam os animais doentes? Vejamos que aproximações se podem fazer, tendo em conta a documentação que chegou até ao presente, proveniente da administração do desembargador João Rodrigues Vilar, iniciada em 1776. Se bem que antes já se fizessem despesas com os animais exóticos, a contabilidade organizada anteriormente misturou os gastos da ucharia com os que eram destinados aos cuidados dos animais. A partir de julho de 1776 e até dezembro de 1799, tudo se modificou e as despesas passaram a ter rubricas diferenciadas. Ou seja, para a análise que se segue temos dados sistemáticos apenas para parte do reinado de D. Maria I.

As despesas com os animais régios incluíam os gastos com a alimentação, as gaiolas, as jaulas, os fretes de vários materiais, designadamente os alimentos; alguns objetos e ainda os ordenados dos tratadores. Se inicialmente, antes da segunda metade de 1776, as contas apresentaram as verbas despendidas com os animais para mera exibição e deleite - aves canoras, elefantes, felinos diversos e zebras - com os dos que serviam fins utilitários como os cavalos, as vacas e as aves de caça, posteriormente tudo se simplificou.

João Rodrigues Vilar apresentou três rubricas relativas a despesas com animais, isto é, as vacas, as «aves e bichos» e as zebras. Esta distinção, que não primou nem pela clareza nem por se basear em qualquer critério científico, tinha uma contabilidade diferenciada quer em relação aos ordenados dos que cuidavam dos animais quer em relação às verbas utilizadas na alimentação, cuidados veterinários e todo um conjunto de gastos diversos desde a aquisição de jaulas e de gaiolas, passando pelo transporte dos animais das embarcações até ao Pátio dos Bichos. Mesmo assim, nas despesas particulares, uma outra rubrica, encontram-se esporadicamente gastos com os animais lúdicos.

${ }^{46}$ Isabel M. R. Mendes Drumond Braga, Missões diplomáticas entre Portugal e o Magrebe no século XVIII. Os relatos de frei João de Sousa (Lisboa: Centro de Estudos Históricos, 2008), 23-24. 
Das vacas - utilizadas na alimentação da Casa Real - tratavam os moços Francisco Alves, Sebastião Alves e António Alves, cujos ordenados e comedorias eram de 6.400 mensais para cada um dos primeiros e 4.800 para o terceiro. As restantes despesas eram, especialmente, com a alimentação, os cuidados veterinários e a iluminação, isto é, as «luzes da cavalariça das vacas». Só esta implicava mais de 40.000 réis por mês em azeite. Desta rubrica das vacas, atendendo a que não eram animais lúdicos, não nos ocuparemos.

As parcelas sob designação «aves e bichos» referiram-se sempre a todos os animais, com exceção de zebras e de bovinos não destinados nem ao trabalho nem ao consumo. Aqui se encontraram um paquiderme, um ou dois ursos, diversos felinos, uma imensa variedade de aves, peixes e todo um conjunto de outros animais diversos, especialmente oriundos de paragens exóticas, com destaque para o Brasil. Finalmente, a última rubrica, era designada por «caderno das zebras». Estas duas partes constituíram os gastos com os animais exóticos destinados à exibição.

Com base nas despesas do Pátio dos Bichos podemos verificar que o elefante, o mais oneroso dos animais, era alimentado com arroz, por vezes comia favas e ervilhas e, esporadicamente, cocos, além de beber vinho. Os felinos - designados indistintamente por leopardos (Panthera pardus), onças (Phantera onca ou Puma concolor) e tigres (Phantera tigris), numa suposta e comum imprecisão de nomenclatura comiam carne. As verbas relativas a este alimento apareciam destinadas como para «aves e bichos», nunca precisando as espécies. A dieta do urso era paupérrima e limitada a pão, tal como a da anta e as dos macacos. Já as zebras, os bois de Angola e os bois corcunda, isto é, os zebus, consumiam cevada, milho e, sazonalmente, «verde», isto é, pasto. Os porcos alimentavam-se de hortaliça, de cevada e de castanhas. O «bicho tamanduá», ocupante do Pátio dos Bichos a partir de $1786^{47}$, começou por beber leite, tendo passado a comer carne, o que evidencia ter chegado ainda pequeno. As aves, muito diversificadas, apesar de raramente haver informações sobre as espécies, com exceção de águias, araras, canários, emas, faisões, galinhas de Angola, galinhas pintadas, gansos, grous, mutuns, papagaios, pavões, periquitos, perus brancos, rolas, tucanos e até um «pássaro arabu», ou seja um urubu, chegado em $1781^{48}$, eram alimentadas com carne, no caso das de rapina; e com alpista, ervilhaca, milho, sêmeas e até ovos, destinados, em especial mas não exclusivamente, aos canários. Os peixes dos tanques recebiam pão. Em alguns momentos foram ainda adquiridas quantidades de feijão branco e de feijão-frade mas não se sabe a que espécies se destinavam. A alimentação de um camelo e de corsas, cutias, lobos e porcos-espinhos nunca foi indicada. Se existiam répteis nunca os mesmos foram referidos.

${ }^{47}$ Lisboa, ANTT, Casa Real, cx. 3609.

${ }^{48}$ Lisboa, ANTT, Casa Real, cx. 3599. 
Os gastos com a alimentação dos animais foram conhecendo alterações ao longo do período em estudo. As modificações em alta dos preços ${ }^{49}$ foram relevantes, em particular no caso da cevada, do milho e do trigo, em alguns casos ultrapassando os $50 \%$, mas também esteve em causa o número de bichos, cujo total numa foi referido, mas que foi crescendo ${ }^{50}$.

Note-se que a morte do elefante, em 1781, com o qual se gastava de 40.000 a 50.000 réis por mês, fez baixar a despesa anual de forma muito acentuada. Em 1789, sem novo paquiderme, as verbas gastas anualmente voltaram a atingir quantitativos muito elevados que se mantiveram até ao final do período para o qual estas informações estão disponíveis. Esta fase caracteriza-se pelo referido crescimento dos preços e pela presença de um ou dois ursos no Pátio dos Bichos. De facto, quando o desembargador João Rodrigues Vilar assumiu a administração havia um exemplar que faleceu em 1779. Novo animal chegou em 1794 e mais um em 1798. Na década de 1790 gastavam-se 60 réis por dia em pão, para cada animal, o que ao fim de um ano totalizava 43.800 réis, quase tanto como o que implicava manter um elefante mensalmente. Em seis anos, a média mensal de gastos ultrapassou os 100.000 réis $^{51}$.

Quadro 1: Média mensal dos gastos (em réis) com as aves e bichos (1776-1799)

\begin{tabular}{|l|r|r|}
\hline Anos & Quantia Total & Média Mensal \\
\hline $1776^{52}$ & 453.365 & 75.561 \\
\hline 1777 & 1.324 .148 & 110.346 \\
\hline 1778 & 1.145 .353 & 95.455 \\
\hline 1779 & 1.333 .356 & 111.113 \\
\hline 1780 & 1.209 .008 & 100.751 \\
\hline 1781 & 1.388 .281 & 115.690 \\
\hline 1782 & 711.623 & 59.302 \\
\hline 1783 & 835.572 & 69.631 \\
\hline 1784 & 686.121 & 57.177 \\
\hline 1785 & 763.215 & 63.601 \\
\hline 1786 & 746.868 & 62.239 \\
\hline 1787 & 918.361 & 76.530 \\
\hline 1788 & 970.405 & 80.867 \\
\hline
\end{tabular}

$49 \mathrm{O}$ quadro foi realizado com base nos preços indicados em ANTT, Casa Real, cxs 3590, 3628 e 3629.

${ }^{50}$ Isabel M. R. Mendes Drumond Braga, "Descobrir e Juntar Animais: 'Novas Novidades', Pátio dos Bichos e Jardim Zoológico de Lisboa", em Animais e companhia na História de Portugal, dir. Isabel Drumond Braga et Paulo Drumond Braga (Lisboa: Círculo de Leitores, 2015), 317-389.

${ }^{51} \mathrm{O}$ quadro foi realizado com base nas rubricas constantes em ANTT, Casa Real, cxs 3590-3630.

52 Só engloba os meses de julho a dezembro. 


\begin{tabular}{|l|r|r|}
\hline 1789 & 1.137 .557 & 94.796 \\
\hline 1790 & 1.445 .487 & 95.128 \\
\hline 1791 & 1.184 .475 & 98.706 \\
\hline 1792 & 1.139 .992 & 94.999 \\
\hline 1793 & 1.299 .767 & 108.314 \\
\hline 1794 & 1.528 .180 & 127.180 \\
\hline 1795 & 1.108 .275 & 92.356 \\
\hline 1796 & 1.090 .477 & 90.873 \\
\hline 1797 & 1.114 .485 & 92.874 \\
\hline 1798 & 1.114 .485 & 92.874 \\
\hline 1799 & 1.069 .353 & 89.113 \\
\hline
\end{tabular}

Como já se referiu, na contabilidade do desembargador João Rodrigues Vilar todos os gastos com as zebras (Equus žbra) ocuparam um espaço à parte, designado como «caderno das zebras». Ao longo do período em estudo, estes equídeos partilharam o espaço com zebus (Bos taurus indicus) e bois de Angola (Bos taurus brachicerus). À medida que as zebras iam falecendo aumentavam os bovinos. Em quase nenhum momento se conseguiu perceber de forma precisa quantos eram. Já das zebras sabemos um pouco mais, pois no princípio de 1776 , eram 13, tendo falecido uma em março. Curiosamente, um rol elaborado nesse ano forneceu os nomes de todos os animais, uma maneira de os distinguir uns dos outros: Açucena, Agia, Andesina, Ásia, Babona, Carapeta, Limose, Morgada, Morgado, Novelo, Pérola, Princesa (morreu a 7 de março) e Verboneta ${ }^{53}$. Sabe-se que inicialmente chegou um casal destes equídeos que se reproduziram bastante bem mas, posteriormente, as mortes das zebras foram-se sucedendo sem renovação nem de animais nascidos em cativeiro nem de exemplares provenientes de África.

Os gastos com as zebras incluíam os ordenados de três moços que cuidavam delas: António José, Pedro Henriques e José Henriques. Todos sabiam assinar. Cada um recebia mensalmente 4.800 réis, bem menos do que era gasto com a alimentação dos animais. Uma ou duas vezes por ano, eram pagos 480 réis para aparar os cascos das zebras e, mensalmente, adquiria-se azeite para iluminar a «cavalariça das zebras». Esporadicamente consertava-se um bornal. Apesar de os gastos com as zebras e com os bois ${ }^{54}$ serem bastante mais baixos do que com as «aves e bichos» mesmo assim representaram parcelas importantes.

Quadro 2: Média mensal dos gastos com as zebras e com os bois (1776-1799)

${ }^{53}$ Lisboa, A.N.T.T., Casa Real, cx. 3590. Sobre a prática de dar nomes aos animais, cf. Keith Thomas, Man and natural world: changing attitudes in England 1500-1800 (Londres: Penguin Books, 1984), $113-115$.

$54 \mathrm{O}$ quadro foi realizado com base nas rubricas constantes em ANTT, Casa Real, cxs 3590-3630. 


\begin{tabular}{|c|c|r|}
\hline Anos & Quantia & Média Mensal \\
\hline 1776 & 612.640 & 51.053 \\
\hline 1777 & 509.670 & 42.473 \\
\hline 1778 & 350.945 & 29.245 \\
\hline 1779 & 332.165 & 27.680 \\
\hline 1780 & 291.800 & 24.316 \\
\hline 1781 & 274.795 & 22.899 \\
\hline 1782 & 266.065 & 22.172 \\
\hline 1783 & 288.775 & 24.064 \\
\hline 1784 & 320.580 & 26.715 \\
\hline 1785 & 282.775 & 23.564 \\
\hline 1786 & 313.010 & 26.084 \\
\hline 1787 & 299.705 & 24.975 \\
\hline 1788 & 308.980 & 25.748 \\
\hline 1789 & 307.930 & 25.660 \\
\hline 1790 & 374.160 & 31.180 \\
\hline 1791 & 438.805 & 36.567 \\
\hline 1792 & 448.730 & 37.394 \\
\hline 1793 & 624.030 & 52.002 \\
\hline 1794 & 538.455 & 44.871 \\
\hline 1795 & 527.580 & 43.965 \\
\hline 1796 & 474.385 & 39.532 \\
\hline 1797 & 492.380 & 35.781 \\
\hline 1798 & 493.600 & 41.133 \\
\hline 1799 & 418.285 & 34.857 \\
\hline & & \\
\hline
\end{tabular}

Em 23 anos os gastos com animais exóticos atingiram, por defeito, uma vez que algumas verbas foram integradas na rubrica das despesas particulares, 34.230.286 réis, uma média de 1.488 .273 réis por ano. As oscilações variaram entre um mínimo, em 1782, após a morte do elefante, de 977.688 réis, e um máximo de 2.006.635, em 1794. As «aves e bichos» implicaram sempre gastos mais elevados, o que se compreende cabalmente pois esta categoria incluía muitos animais, embora nunca se saiba quantos. 


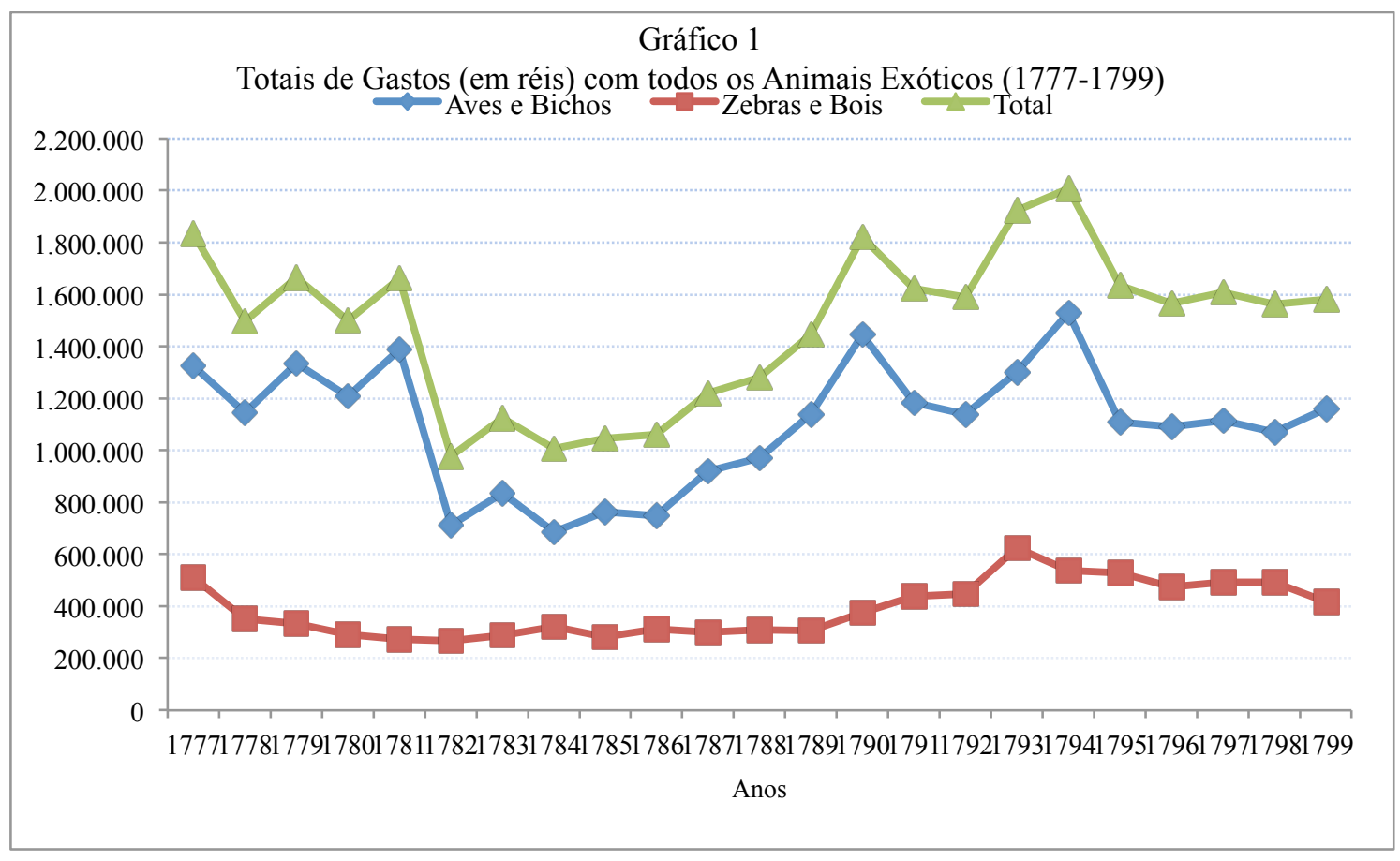

Tendo em conta os gastos totais realizados no Paço de Belém, incluindo consequentemente, os bens adquiridos, as obras realizadas e os ordenados dos que lá trabalhavam, pode verificar-se que a percentagem dos gastos com os animais exóticos foi muito variável, registando-se um mínimo de 8,5\%, em 1799, o último ano em análise, e um máximo de $26,3 \%$, em 1779 . Neste caso, as despesas com os bichos ultrapassaram um quarto da despesa total ${ }^{55}$.

Quadro 3: Percentagem dos gastos (em réis) com todos os animais exóticos (1777-1799)

\begin{tabular}{|c|c|r|r|r|c|}
\hline Anos & $\begin{array}{l}\text { Aves e } \\
\text { Bichos }\end{array}$ & $\begin{array}{c}\text { Zebras e } \\
\text { Bois }\end{array}$ & $\begin{array}{c}\text { Despesa Total } \\
\text { Dos Animais } \\
\text { Exóticos }\end{array}$ & $\begin{array}{c}\text { Despesa Total } \\
\text { do Paço }\end{array}$ & $\begin{array}{c}\text { Percentagem } \\
\text { dos gastos com } \\
\text { os Animais } \\
\text { Exóticos }\end{array}$ \\
\hline 1777 & 1.324 .148 & 509.670 & 1.833 .818 & 7.690 .358 & 23,9 \\
\hline 1778 & 1.145 .335 & 350.945 & 1.496 .280 & 7.615 .976 & 19,7 \\
\hline 1779 & 1.333 .356 & 332.165 & 1.665 .521 & 6.329 .675 & 26,3 \\
\hline 1780 & 1.209 .008 & 291.800 & 1.500 .808 & 6.460 .888 & 23,2 \\
\hline 1781 & 1.388 .281 & 274.795 & 1.663 .076 & 7.484 .916 & 22,2 \\
\hline 1782 & 711.623 & 266.065 & 977.688 & 7.102 .252 & 13,8 \\
\hline
\end{tabular}

$55 \mathrm{O}$ quadro foi realizado com base nas rubricas constantes em ANTT, Casa Real, cxs 3590-3630. 


\begin{tabular}{|l|r|r|r|r|c|}
\hline 1783 & 835.572 & 288.775 & 1.124 .347 & 8.306 .920 & 13,5 \\
\hline 1784 & 686.121 & 320.580 & 1.006 .701 & 10.459 .635 & 9,6 \\
\hline 1785 & 763.215 & 282.775 & 1.045 .990 & $?$ & - \\
\hline 1786 & 746.868 & 313.010 & 1.059 .878 & 10.588 .318 & 10,0 \\
\hline 1787 & 918.361 & 299.705 & 1.218 .990 & 11.761 .508 & 10,4 \\
\hline 1788 & 970.405 & 308.980 & 1.279 .385 & 13.507 .762 & 9,5 \\
\hline 1789 & 1.137 .557 & 307.930 & 1.445 .487 & $?$ & - \\
\hline 1790 & 1.445 .487 & 374.160 & 1.819 .647 & 17.732 .583 & 10,3 \\
\hline 1791 & 1.184 .475 & 438.805 & 1.623 .280 & 15.705 .883 & 10,3 \\
\hline 1792 & 1.139 .992 & 448.730 & 1.588 .722 & 16.216 .980 & 9,8 \\
\hline 1793 & 1.299 .767 & 624.030 & 1.923 .797 & 15.399 .940 & 12,5 \\
\hline 1794 & 1.528 .180 & 538.455 & 2.006 .635 & 18.722 .570 & 10,7 \\
\hline 1795 & 1.108 .275 & 527.580 & 1.635 .855 & 14.750 .158 & 11,1 \\
\hline 1796 & 1.090 .477 & 474.385 & 1.564 .862 & 15.266 .702 & 10,3 \\
\hline 1797 & 1.114 .485 & 492.380 & 1.606 .855 & 14.683 .608 & 11,0 \\
\hline 1798 & 1.069 .353 & 493.600 & 1.562 .953 & 14.461 .126 & 10,8 \\
\hline 1799 & 1.161 .426 & 418.285 & 1.579 .711 & 18.494 .868 & 8,5 \\
\hline
\end{tabular}

Comparemos os gastos com a fauna exótica do Pátio dos Bichos com os valores de alguns ordenados e com o preço das pessoas cativas no Islão. Em 1778, foi realizado um resgate em Argel, no qual foram obtidos 223 indivíduos a troco de 152.537.756 réis. O preço médio por pessoa foi de 684.025 réis, o que escondeu grandes assimetrias pois a aquisição mais elevada foi de 1.679 .500 réis e a mais barata de 345.700 réis $^{56}$. Ou seja, alimentar anualmente um elefante custava, em média, entre 480.000 e 600.000 réis, isto é, mais do que o resgate de alguns seres humanos. Vejamos o que se pode concluir tendo em conta os salários. Sabendo-se que um mestre carpinteiro ou um mestre pedreiro auferiam, em 1775, diariamente 450 réis, uma média mensal de 11.250 réis, ou seja cerca de 135.000 réis por ano ${ }^{57}$, percebemos que só os gastos com as zebras equivaliam, no mínimo, a três vencimentos anuais de mestres carpinteiros ou de mestres pedreiros. A situação era ainda pior se nos referíssemos a um aprendiz dos mesmos ofícios, cujas jornas oscilavam entre 100 e 240 réis e 160 e 240 réis, respetivamente para o aprendiz de carpinteiro e de pedreiro ${ }^{58}$. Nestes casos, só os cuidados com as zebras eram

56 Isabel M. R. Mendes Drumond Braga, "O Resgate geral de cativos enquanto obra de assistência: o caso de 1778”, em Cultura, religião e quotidiano: Portugal (século XVIII) (Lisboa: Hugin Editores, 2005), 233-264.

${ }^{57}$ Vitorino Magalhães Godinho, Prix et monnaies au Portugal 1750-1850 (Paris : Armand Colin, 1955), 193.

58 Ibidem, 193. 
semelhantes a um máximo de 10 ordenados e a um mínimo de cinco. Se tivermos em conta os ordenados anuais dos funcionários do Desembargo do Paço, na mesma época, podemos verificar que o do escrivão da comarca era de 600.000 réis, ou seja, permitia sustentar as zebras e ainda alguns outros animais durante um ano. Já os vencimentos anuais do desembargador, no valor de 1.200.000 réis, ou do escrivão da justiça, que ascendia a 1.500 .000 réis $^{59}$, poderiam dar para cuidar de toda a bicharia.

O Pátio dos Bichos manter-se-á em funcionamento até 1884, quando se inaugurou o Jardim Zoológico e de Aclimatação de Lisboa ${ }^{60}$, situado em São Sebastião da Pedreira, o único então existente na Península Ibérica. Porém, muito depois de outras realizações semelhantes em várias partes da Europa. Sabe-se que diversos membros da família real - caso dos monarcas D. Luís, D. Maria Pia, D. Fernando e sua segunda mulher a condessa de Edla - ofereceram alguns bichos. De notar que D. Luís aproveitou para oferecer 17 animais, entre eles dois ursos e, assim, extinguir o Pátio dos Bichos. O novo espaço apresentou uma vocação mais lúdica do que instrutiva e pouco relevante em termos de utilidade para o desenvolvimento económico do reino.

A designação jardim zoológico datou da primeira metade do século XIX e rapidamente se tornou corrente em França e na Grã-Bretanha, vindo substituir o termo francês ménagerie, que designava o local onde se concentravam os animais raros e perigosos por razões de prestígio ou de deleite dos monarcas e dos nobres, leigos e eclesiásticos, com meios para manterem tais luxos ${ }^{61}$. Basicamente, a diferença entre ménagerie e jardim zoológico residiu no estatuto. Isto é, enquanto o primeiro termo implicava um empreendimento particular, para uso restrito, e um acondicionamento dos animais em vários espaços nem sempre construídos especificamente para o efeito, os segundos foram empreendimentos nacionais, municipais ou privados em nome coletivo, nos quais se dispuseram os animais em jardins e em jaulas e outras instalações construídas para os acolher ${ }^{62}$. Se inicialmente nas ménageries estava em causa o prestígio do possuidor visível através da capacidade de comprar, manter,

\footnotetext{
${ }^{59}$ Sobre os vencimentos dos funcionários do Desembargo do Paço, cf. José Manuel Louzada Lopes Subtil, O Desembargo do Paço (1750-1833) (Lisboa: Universidade Autónoma de Lisboa, 1996), 90.

${ }^{60}$ Braga, Descobrir, e a bibliografia aí citada.

${ }^{61}$ Localizaram-se ménageries durante a Época Medieval em França, Inglaterra, Sacro Império Romano-Germânico, Península Itálica e Polónia. Cf. Lisa J. Kiser, "Animals in Medieval Sports, Entertainment and Ménageries", em A Cultural History of Animals in the Medieval Age, direção de Brigitte Resl, (= A Cultural History of Animals, direção geral de Linda Kalof e Brigite Rels 2) (Oxford: Nova Iorque, Berg, 2011), 105-107.

${ }^{62}$ Sobre estas questões, cf. Éric Baratay, "Un instrument symbolique de la domestication: le Jardin Zoologique aux XIX et XXe siècles (L'exemple du Parc de la Tête d'Or à Lyon", Cabiers d'Histoire [on line], n. ${ }^{\circ}$ 42-3/4, (1997), consultado a 21 de Agosto de 2014. URL : http://ch.revues.org/314; Idem, "La visite au Zoo: regards sur l'animal captive 1793-1950", em L'Animal sauvage entre nuisance et patrimoine: France XVI-XXI siècles, direcção de Stéphanie Frioux e Émile-Anne Pépy, (Lyon : Ens Editions, 2009), 165-175.
} 
oferecer e receber animais, exibindo riqueza e poder, nos jardins zoológicos estava em evidência o gosto do público cada vez mais recetivo ao novo e ao diferente.

Para os monarcas e para os poucos elementos da nobreza e do clero que podiam manter ménageries, a posse e a exibição das coleções de seres vivos permitiam tornar evidente fausto e poderio mas também força e bravura típica das feras. Possibilitava ainda a exaltação do grau de cultura do dono que, em outros contextos, se evidenciava nos gabinetes de curiosidades e nos jardins botânicos. Ou seja, possuir animais exóticos significava também participar no esforço de conhecimento do mundo, permitindo aos naturalistas o estudo das espécies. Estes animais peças de coleção, desprovidas de uso concreto, mas de evidente sentido simbólico, podiam ser entendidos como possuidores de um estatuto próximo das obras de arte, uma vez que apelavam ao gosto do gratuito e ao desdém pelo utilitário, reforçando a diferença face ao resto da sociedade ${ }^{63}$. Afinal, como sistematizou de forma precisa Pierre Bordieu, o usufruto de bens de luxo, passava pela possibilidade de se fazer notar, o que só acontecia tendo em conta que a distinção existe sempre «na e pela relação, na e pela diferença» ${ }^{64}$.

O Pátio dos Bichos, ao contrário de outras distrações da corte, designadamente os divertimentos programados ${ }^{65}$ que integravam um calendário relativamente informal mas conhecido de todos, tais como bailes, representações teatrais, óperas, caçadas e festas religiosas, constituía um espaço concreto, dentro da quinta de Belém, que permitia ao monarca e aos seus convidados usufruir do contato com a natureza, apreciar os animais e os seus comportamentos e deleitar os visitantes, em especial os estrangeiros que não ficavam indiferentes ao exotismo dos bichos e à ostentação régia.

\footnotetext{
${ }^{63}$ Seguem-se aqui as observações pertinentes de Éric Baratay, "Des naturalistes", 165-166.

${ }^{64}$ Pierre Bordieu, La Distinction : critique social du jugement (Paris : Editions de Minuit, 1979), 250.

${ }^{65} \mathrm{Cf}$., sobre este assunto, Frédérique Leferme-Falguières, Les Courtisans: une société de spectacle sous l'Ancien Régime (Paris : PUF, 2007), 253-302.
} 


\section{BIBLIOGRAFIA}

\section{Fontes Manuscritas:}

ANTT, Casa Real, cxs. 3106, 3590-3630.

ANT'T, Ministério dos Negócios Estrangeiros, cx. 627.

\section{Fontes Impressas:}

Inácio de Vilhena Barbosa, Apontamentos para a História das Colecçoes e dos Estudos de Zoologia em Portugal. Lisboa: Cristóvão Augusto Rodrigues, 1885.

Inácio de Vilhena Barbosa, "Palácio Real de Belém", Arcbivo Pittoresco, 5, 28, (1862), 217-218 e 5, 29, (1862): 228-229.

Caetano Beirão, "O Terramoto de Lisboa de 1755: novos documentos", Panorama, III série, 1, (1956).

Blondel, Daubenton, Diderot, d'Alembert, "Cabinet", Encyclopédie on Dictionnaire Raisonné des Sciences, des Arts et des Métiers, direção de Denis Diderot e Jean le Rond d'Alembert, (Paris: Chez Briasson, David, l'Ainé, Le Breton e Durand), 1752, 488-493.

Rafael Bluteau, Vocabulario Portuguez e Latino, 2 e 4, (Coimbra, Real Colégio das Artes da Companhia de Jesus, 1712-1713).

Gomes de Brito, "Os pachidermes do Estado d'el-rei D. Manuel”, Revista de educação e ensino e archivo de inéditos históricos, 9, (1894): 79-86.

Cancioneiro Geral de Garcia de Resende 4. Lisboa: Imprensa Nacional Casa da Moeda, 1993.

Damião de Góis, Crónica do felicíssimo rei D. Manuel. Coimbra: Imprensa da Universidade de Coimbra, 1955.

Leonor de Portugal, imperatriz da Alemanha: diário da viagem do embaixador Nicolau Lanckman de Valckenstein. Lisboa: Edições Cosmos, 1992.

Garcia de Resende, Crónica de Dom João II e Miscelânea. Lisboa: Imprensa Nacional Casa da Moeda, 1973.

Terramoto (O) de 1755: narrativa de uma testemunha ocular. Lisboa: Livraria Ferin, 1953. 


\section{Estudos:}

Anna M. Adroer i Tasis, "Animals exòtics als palaus reials de Barcelona”, Medievalia, 8, (1989): 9-22.

Éric Baratay, "Des naturalistes dans les cages : l'exemple de Claude Perrault (16131688)", em La bête captive au Moyen Áge et à l'Époque Moderne, direção de Corine Beck e Fabrice Guizard-Duchamp. Amiens : Encrage, 2012, 161-176.

Éric Baratay, "La visite au Zoo: regards sur l'animal captive 1793-1950", em L'Animal sauvage entre nuisance et patrimoine: France XVI-XXI siècles, direcção de Stéphanie Frioux e Émile-Anne Pépy. Lyon : Ens Editions, 2009, 165-175. https://doi.org/10.4000/books.enseditions.6507

Éric Baratay, "Un instrument symbolique de la domestication: le Jardin Zoologique aux XIX ${ }^{\mathrm{e}}$ et $\mathrm{XX}^{\mathrm{e}}$ siècles (L'exemple du Parc de la Tête d'Or à Lyon", Cahiers d'Histoire [on line], n. ${ }^{\circ}$ 42-3/4, 1997, consultado a 21 de Agosto de 2014. URL : http://ch.revues.org/314.

Silvio A. Bedini, The pope's elephant. Manchester: Carcanet Press, 1997.

Lucien Bély, Espions et ambassadeurs au temps de Louis XIV. Paris : Fayard, 1990.

François Bertrandy, "Remarques sur le commerce des bêtes sauvages entre l'Afrique du Nord et l'Italie (II $\mathrm{e}^{\mathrm{e}}$ siècle avant JC, IV siècle après JC)", Mélanges de l'École Française de Rome. Antiquité, 99, 1 (1987) : 211-241.

Pierre Bordieu, La Distinction: critique social du jugement. Paris : Editions de Minuit, 1979.

Isabel M. R. Mendes Drumond Braga, "Descobrir e Juntar Animais: 'Novas Novidades', Pátio dos Bichos e Jardim Zoológico de Lisboa”, em Animais e companbia na História de Portugal, direção de Isabel Drumond Braga e Paulo Drumond Braga. Lisboa: Círculo de Leitores, 2015, 317-389.

Isabel M. R. Mendes Drumond Braga, "D. Rafael Bluteau na Corte Portuguesa (1668-1734," Cultura, Religião e Quotidiano. Portugal (século XVIII) (Lisboa: Hugin, 2005) 7-82.

Isabel M. R. Mendes Drumond Braga, "O Resgate geral de cativos enquanto obra de assistência: o caso de 1778”, em Cultura, religião e quotidiano: Portugal (século XVIII). Lisboa: Hugin Editores, 2005, 233-264. 
Isabel M. R. Mendes Drumond Braga, Missões diplomáticas entre Portugal e o Magrebe no século XVIII. Os relatos de frei João de Sousa. Lisboa: Centro de Estudos Históricos, 2008.

Isabel M. R. Mendes Drumond Braga, Um Espaço, duas Monarquias: Inter-Relações na Peninsula Ibérica no Tempo de Carlos V. Lisboa: Centro de Estudos Históricos da Universidade Nova de Lisboa, Hugin Editores, 2001.

Paulo Drumond Braga, A Rainha discreta: Mariana Vitória de Bourbon, Lisboa: Círculo de Leitores, 2014.

Thierry Buquet, "Les Animaux exotiques dans les ménageries médievales", em Fabuleuses histoires des bêtes et des hommes, direção de Jacques Toussant. Namur : Trema, 2013, 97-121.

Thierry Buquet, "Les ménageries arabes et ottomanes", SSMOCI - Société Suisse Moyen Orient et Civilisation Islamique, 38, n. especial (Tière l'Animal) (2014) : 16-19.

Maureen Cassidy-Geiger (dir.), Fragile diplomacy : Meissen porcelain for European courts ca. 1710-68. Nova Iorque, Yale University Press, 2008.

Abel Fontoura da Costa, Deambulations of the rbinoceros (Ganda) of Muzafar, king of Cambaia, from 1514 to 1516. Lisboa: Agência Geral das Colónias, 1937.

Doni (I) di Shah Abbas il grande alla Serenissima: relarioni diplomatiche tra la Repubblica di Venezia a la Persi Safavide, direção de Elisa Gagliardi Mangiilli. Veneza: Marsilio Editori, 2013.

Felipe II un monarca y su época: un príncipe del Renascimiento. Madrid: Sociedad Estatal para la Conmemoración de los Centenarios de Felipe II y Carlos V, 1998.

Vitorino Magalhães Godinho, Prix et monnaies au Portugal 1750-1850. Paris : Armand Colin, 1955.

Carlos Gómez-Centurión Jiménez, Alhajas para los soberanos: los animales reales en el siglo XVIII: de las leoneras a las mascotas de cámara. [Valladolid]: Junta de Castilla y Leon, 2011.

Deborah Howard, "Cultural transfer between Venice and the Ottomans in the fifteenth and sixteenth centuries," em Cultural exchange in Early Modern Europe: forging European identities: 1400-1700, 4. Cambridge: Cambridge University Press, 2007, 38-177. 
Annemarie Jordan-Gschwend, “A Procura portuguesa por animais exóticos”, em Cortejo triunfal com girafas: animais exóticos ao serviço do poder. Lisboa: Fundação Ricardo do Espírito Santo Silva, 2009, 33-42.

Annemarie Jordan-Gschwend, A Rainha colecionadora: Catarina de Austria. Lisboa: Círculo de Leitores, 2012.

Annemarie Jordan-Gschwend, The story of Süleyman: celebrity elephants and other exotics in Renaissance Portugal. [s. 1.]: A Pachyderm Production, 2010.

Lisa J. Kiser, "Animals in Medieval Sports, Entertainment and Ménageries", em $A$ Cultural History of Animals in the Medieval Age, direção de Brigitte Resl, $(=A$ Cultural History of Animals, direção geral de Linda Kalof e Brigite Rels 2). Oxford: Nova Iorque, Berg, 2011, 103-126.

Jean-Bernard Lacroix, "L'approvisionnement des ménageries et des transports d'animaux sauvages par la Compagnie des Indes au XVIII ${ }^{\mathrm{e}}$ siècle", Revue française d'histoire d'autre-mer, 65, 239, (1978) : 153-179.

Frédérique Leferme-Falguières, Les Courtisans: une société de spectacle sous l'Ancien Régime. Paris : PUF, 2007.

Gustav Loisel, Histoire des ménageries de l'Antiquité à nos Jours 1. Paris : Octave Doins et Fils e Henri Laurens, 1912.

Paulo Lopes, Um agente Português na Roma do Renascimento. Lisboa: Temas e Debates, Círculo de Leitores, 2013.

José Alberto G. Machado, Um Coleccionador Português do século das Lužes: D. Frei Manuel do Cenáculo Vilas-Boas, Arcebispo de Évora (Évora: Publicações Ciência e Vida, 1987).

Dolores Carmen Morales Muñiz, "La fauna exótica en la Península Ibérica: apuntes para el estudio del coleccionismo animal en el Medievo Hispánico", Espacio, Tiempo y Forma, 3. ${ }^{a}$ série, 13 (2000): 9-22.

Arturo Morgado García, La imagen del mundo animal en la España moderna. Cádiz: UCA, 2015.

Gözde Önder, "Ceramics and carpets: icons of cultural exachange between Venice and the Ottoman Empire in the $16^{\text {th }}$ Century", Diogenes, 2 (2014), 70-94.

Michel Pastoureaux, Les animaux célébres. Paris : Arléa, 2008. 
Almudena Pérez de Tudela, "Algunos regalos diplomáticos devocionales para Felipe II y su familia", in La Corte en Europa: politica y religión (siglos XVI-XVIII), direção de José Martínez Millán, Manuel Rivero Rodríguez, Gijs Versteegen. Madrid : Polifemo, 2012, 1795-1849.

Almudena Pérez de Tudela, Annemarie Jordan-Gschwend, "Renaissance menageries: exotics animals and pets at the Habsbourg courts in Iberia and Central Europe", em Early Modern zoology: the construction of animals in science, literature and visual arts 1. Leiden: Brill, 2007, 427-456. https://doi.org/10.1163/ej.9789004131880.i-657.103

María Ángeles Pérez Samper, Isabel de Farnesio. Barcelona: Plaza Janés, 2003.

Joan Pieragnoli, La cour de France et ses animaux (XVI $T^{e}-X V I I^{e}$ siècles). Paris : PUF, 2016.

Ricardo Ferreira Ribeiro, "A Triste e mal sucedida epopeia transatlântica da onça que 'morreo de raiveza ferrando os dentes num pao': o tráfico de animais no Brasil colônia”, III Encontro da ANPPAS. Brasília: [s.n.], 2006, 1-16.

Mariagrazia Russo, "Un Elefante per bagaglio tra arte, storia e letteratura: il regalo di D. João III a Massimiliano d'Austria attraverso l'Europa del Cinquecento", em Viaggio con José Saramago, Bagagli e Oggetti da Viaggio, direcção de Cinzia Capitoni. Viterbo: Sette Città, 2011, 23-36.

Jean-François Solnon, Le turban et la stambouline: l'empire Ottoman et l'Europe, $X I V^{e}-X X^{e}$ siècles: affrontement et fascination réciproques. Paris : Perrin, 2009.

José Manuel Louzada Lopes Subtil, O Desembargo do Paço (1750-1833). Lisboa: Universidade Autónoma de Lisboa, 1996.

Keith Thomas, Man and natural world: changing attitudes in England 1500-1800. Londres: Penguin Books, 1984.

Antonio Urquízar Herrera, Coleccionismo y Nobleza. Signos de Distinción Social en la Andalucía del Renascimiento (Madrid: Marcial Pons, 2007).

Lucette Valensi, Ces étrangers familiers: musulmans en Europe (XVI-XVIII siècles). Paris : Éditions Payot \& Rivages, 2012.

Beatrice Palma Venetucci, Dallo Scavo al Collezionismo. Un Viaggio nel Passato dal Medioevo all'Ottocent, (Roma: De Luca Editori, 2007). 
Recibido: 18 de mayo de 2018 Aprobado: 1 de noviembre de 2018 